\title{
THE EFFECT OF IMPLEMENTATION OF GOOD CORPORATE GOVERNANCE, COMPANY SIZE, AND FREE CASH FLOW ON EARNINGS MANAGEMENT
}

\author{
Fina Fitriyana \\ ${ }^{1}$ Accounting, Economy, Pamulang University, Jl. Surya Kencana No. 1, South Tangerang, 15412, Indonesia \\ E-mail : dosen02518@unpam.ac.id
}

\begin{abstract}
The aims of this study is to examine the effect of the good corporate governance, company size, and free cash flow on the earnings management for companies in food and beverage sector at Indonesia Stock Exchange in period of 2012 until 2016. This study conducts regression analysis in term of hypothesis testing. This study finds that board of directors and board of commissioners are significant on earnings management, while the commissioners and audit committee, firm size and free cash flow are insignificant.

Keywords: board of directors; board of commissioners; audit committee; company size; free cash flow; earnings management

JEL Classification: G30, G34, O16
\end{abstract}

Article info:

Received 10 December 2020

Revised 10 December 2020

Accepted 10 December 2020

Available online 10 December 2020

\section{INTRODUCTION}

Earnings information is an important part of the financial statement because this information is generally viewed as a representation of management performance in a particular period (Handayani and Rachadi, 2009). However, although the earnings information is important, the investor tends to forget to pay attention to how the management works in the process of generating that earnings. This can encourage management to manipulate earnings or more commonly known as earnings management. The implementation of good corporate governance can be traced to the development of agency theory. Jensen and Meckling (1976) describe that agency relationship as "agency relationship as a contract under which one or more person (the principals) engage another person (the agent) to perform some service on their behalf which involves delegating some decision making authority to the agent".

The implementation of good corporate governance must be supported by company organ that must carry out its functions in accordance with the provisions and carry out duties, functions and responsibilities solely for the benefit of the company. The corporate organs that are meant here are the General Meeting of Shareholders (or called RUPS), the Board of Directors, the Board of Commissioners and other corporate organs that can help the implementation of good corporate governance, such as the audit committee. Board of directors is a management system that is responsible for implementing good corporate governance to achieve company's goals. In addition to the importance of implementing good corporate governance in suppressing the earnings management practice within the company, company size also plays an important role in earnings management practice. According to Mahiswari and Nugroho (2014), the small company is considered to be more likely to practice earnings management than a large company. This is due to attracting investors to invest in the company. On the other hand, there are factors that influence earnings 
management, which is, free cash flow. Company that has high cash flow will have a greater chance of conducting earnings management. This is because the managerial side does not make optimal use of the available free cash.

Some empirical evidences show the factors that influence earnings management. Handoko (2014) proves that good corporate governance has principles that help company implement the good corporate governance in a good way. Good corporate governance can minimize the risk of misstatement of information so that it can present qualified information, thus investors can trust the presented information. Handayani and Rachadi (2009) prove that medium and large companies were not proven to be more aggressive in carrying out earnings management through positive earnings reporting mechanisms, both to avoid earnings losses and earnings decreases. Agustia (2013) proves that free cash flow has negative and significant effect on earnings management which means that companies with high free cash flow will hinder earnings management practices.

\section{LITERATURE REVIEW}

\subsection{Agency theory}

Jensen and Meckling (1976) argue that agency theory is the relationship between the shareholders as the principals and the management as the agent where conflicts of interest that occur between company owners and managers can lead to asymmetric information. Jensen and Meckling (1976) also explain that management as the company manager knows more and can more easily access company information and as result, the agent has the opportunity to manipulate numbers and information about the performance of the company. Eventually, the agent does not disclose the true information about the condition of the company to the principal, especially if that information is an indicator to measure the agent's performance.

\subsection{The basic concepts}

Earnings management. Earnings management is defined as a manager's attempt to engineer financial statements within the permitted limits allowed by accounting principles which cause asymmetric information to the users of the financial statement (Meutia, 2004). According to Handayani and Rachardi (2009), earnings management is a process where the managers have the ability to use their discretion not to dislcose information to stakeholders or influence their contractual outcome with the shareholders. Based on these definitions, earnings management can be interpreted as an attempt by management to engineer financial statements to give asymmetric information to stakeholders, but within limits that do not violate accounting principles.

Good Corporate Governance. According to FCGI (2002), good corporate governance is a set of regulations that establishes the relationship between shareholders, management, creditors, government, employees and other internal and external stakeholders in relation to the rights and obligations of the concerned parties, or in other words, the system that directs and controls the company. Meanwhile, the Decree of the Minister of State Owned Enterprises Number: Per-01/MBU/ 2011 concerning the implementation of good corporate governance practices in State Owned Enterprises (SOE) defines good corporate governance as a process and structure used by SOE organs to increase business success and company accountability in order to realize the value of shareholder in the long run by paying attention to the interests of other stakeholders, based on laws and regulations and ethical values. Based on the existing definitions, thus good corporate governance is a system or structure used by company to maintain good relationships both from the internal and external sides of the company in order to create a good corporate environment from all aspects with the aim of achieving the goals of the company and increasing company value while still paying attention to the interests of stakeholders. 
The size of the Board of Directors. Based on law No. 40 of 2007 concerning Limited Liability Company, the Board of Directors is a company organ that is authorized and fully responsible to manage the company for the interest of the company, in accordance with the aims and objectives of the company and represents the company both inside and outside the court in accordance with the provisions articles of association. Each member of the board of directors can carry out his/her duties and make decisions in accordance with the division of duties and authorities. However, the implementation of duties by each member of the board of directors remains a shared responsibility.

Proportion of Independent Commissioners. Based on the Decision Letter of the BAPEPAM Chairperson and Financial Institutions No: Kep-643/BL/2012, the definition of independent commissioner is as follows: Independent commissioner is a member of the board of commissioners who comes from outside of the issuer or public company and meets the requirements not a person who works or has the authority and responsibility to plan and lead. The role of the commissioner is expected to minimize agency problems that occur between the board of directors and shareholders (Sochib, 2015).

The number of Audit Committees. The audit committees has an important and strategic role in maintaining the credibility of the preparation of financial statements such as maintaining an adequate monitoring system. According to Gregory (2000), the duties of the audit committee are to provide views on accounting issues, financial statement and explanations, the internal control system as well as independent auditors. When the audit committee functions effectively, the control of the company will improve so that it is expected to reduce agency problems.

Company size. The company size is basically the way of classifying companies into several groups, which are large, medium and small companies. Company scale is a measure used to reflect the size of the company based on the total assets of the company. Large, wellestablished companies will find it easier to obtain capital in the capital market compared to small companies. Hence, large companies have greater flexibility (Agus, 2010).

The free cash flow. The free cash flow is the balance of the calculation of the company's cash flow that has been used for working capital, investment, business development, and etc in one period. Free cash flow has benefits for shareholders or owners and management. Meanwhile, according to Subramanyam and John (2010), free cash flow is a useful derivative of cash flow statement analysis, which is the calculation of free cash flow. Benefits for shareholders are free cash flow that will be distributed in the form of dividends. Some of the benefits of free cash flow for managers as company managers are as follows: (1) free cash flow can be used to fund the investment activities of the company that have a positive net present value; (2) manager can use free cash flow to finance facilities such as office facilities and personal facilities; and (3) free cash flow can be used to increase investment in the company in the form of retained earnings.

\subsection{Hypotheses development}

The size of the board of directors and earnings management. According to Sukandar and Rahardja (2014), through the separation of roles from the board of commissioners, the board of directors has great power in managing all the resources in the company. Some empirical evidence shows that there is an inconsistent relationship between boards of directors and earnings management. In the case of a public company on the Jakarta Stock Exchange in 2004, Pradipta (2011) finds that board size significantly affects earnings management. On the other hand, Juwika and Hani (2015) found that the size of the board of directors did not significantly affect earnings management in the case of manufacturing companies that are listed on the Indonesia Stock Exchange in the period between 2009 and 2013. Putra (2019) finds that board size do not significantly affect earnings management in 
Indonesian Shariah banking for the period 2014-2018. Based on this description, thus the hypothesis of this study is:

\section{H1: The size of the board of directors affects earnings management}

The proportion of independent commissioners and earnings management. Based on Law No. 40 of 2007, the company's articles of association can regulate the existence of 1 (one) or more Independent Commissioners. Law No. 40 of 2007 stated that independent commissioners are a member of the board of commissioners who have no financial relationship, management relationship, share ownership relationship and/or other family relationship with other members of the board of commissioners, directors and/or controlling shareholder or relationship with the bank, which may affect their ability to act independently. Yasmeen and Hermawati (2015) show that the independent Board of Commissioners has no effect on the quality of financial reporting. Based on this description, thus the hypothesis of this study is:

\section{H2: The proportion of the independent commissioner affects earnings management}

The number of audit committees and earnings management. The number of audit committee members in a company should be adjusted to the size and complexity of the company itself. Mutmainnah and Wardhani (2013) show that the more members of the audit committee who have expertise in accounting and finance would have an impact on the better quality of financial statement. Consistently, Nasution and Setiawan (2007) show that the existence of an audit committee had an impact on earnings management, this means that the existing audit committee in the company plays a role as a corporate governance mechanism which is able to reduce the earnings management. Based on this description, thus the hypothesis of this study is:

\section{H3: The number of the audit committees affects earning management}

The firm size and earnings management. Company size reflects how big or small a company is. The size of the company is determined or can be seen from the assets, equity, and sales of the company. Medyawati and Dayanti (2017) find that company size had an impact on earnings management. In contrast to that result, Gunawan et al. (2015) show that company size do not have a significant impact on earnings management. Thus, it shows that the size of the company may not necessarily reduce the possibility of earnings management. Based on this description, thus the hypothesis of this study is:

H4: Company size affects earnings management

The free cash flow and earnings management. Free cash flow is the balance of the cash flow of the company that has been used for working capital, investment, business development, etc in one period. Kodriyah and Fitri (2017) show that free cash flow had a significant impact on earnings management, this means that companies with high free cash flow tend to practice earnings management by increasing reported earnings to cover the actions of managers who did not utilize the company's assets optimally. Furthermore, Agustia (2013) shows that free cash flow had a negative and significant effect on earnings management. Thus, it means that companies with high free cash flow hinder earnings management practices. Based on this description, thus the hypothesis of this study is:

H5: Free cash flow affects earnings management

\section{RESEARCH METHOD}

\subsection{Samples and sampling technique}

The samples of this study are food and beverage companies that are registered at the Indonesia Stock Exchange in the period 2012-2016. Meanwhile, the sampling method used in this study is the purposive sampling methodology, which is a sampling technique using certain consideration and limitation so that the selected sample is relevant to the purpose of the study. The criteria for the sample selection that will be studied are as follows: (a) food 
and beverage companies that were continuously registered at the Indonesia Stock Exchange in the period 2012-2016; (b) companies that published the complete audited financial statement along with the annual financial report ending on $31^{\text {st }}$ December, in the period 20122016; and (c) companies that published financial statement in Indonesian Rupiah (IDR). Based on the sample criteria, there are 16 food and beverages companies that are registered in the Indonesia Stock Exchange over the period 2012-2016.

\subsection{Method of analysis}

Testing the significance of multiple linear regression analysis with panel data using $\mathrm{E}$ Views 8.0 as the data processing program. This multiple linear regression analysis can be used to obtain a comprehensive picture of the thorough relationship between the dependent and independent variables both simultaneously and partially at the 0.05 significance level.

1. Descriptive statistics measurement that is used in this study includes the size of the board of directors, the proportion of independent commissioners, the number of audit committees, the size of the company and free cash flow as the independent variables, and earnings management as the dependent variable.

2. Hypothesis testing

a. Multiple Regression Analysis. Multiple regression analysis is intended to test the simultaneously effect of several independent variables on one dependent variable. By using the following techniques:

Pooled Least Square (Common Effect). It is the simplest panel data model approach because it only combines time series and cross section data. This method usually uses the Ordinary Least Square (OLS) approach or the least squares technique to estimate the data panel model.

Fixed Effect Model (FEM). Fixed effect model is a technique of estimating panel data by using dummy variable to capture the difference in the intercept. The approach with this dummy variable is known as fixed effect model or Least Square Dummy Variable (LSDV) or also known as covariance model.

Random effect model is a panel regression estimation model with the assumption of continuous slope coefficient and different intercept between individuals and time (random effect). The right method to use to estimate random effect is the Generalized Least Square (GLS) as the estimator because it can increase the efficiency of the least square.

b. Correlation Analysis. Correlation is a method to measure the closeness of the relationship (correlation) between the independent and dependent variables by controlling the independent variables to see the natural correlation between the uncontrolled variables.

c. Coefficient of Determination. The value of R2 shows the differences in the independent variables in influencing dependent variables. The value of R2 ranges from 0 to 1 , the greater the value of $\mathrm{R} 2$ means the greater variation of the independent variables, hence causing variation in the dependent variable.

\section{d. Classical assumption test}

Normality test aims to test whether the independent variable regression model, dependent variable or both have a normal distribution or not. One of the methods that is mostly used to test normality is the JB-test. Ghozali and Ratmono (2013) state that the JB-test is a normality test for large sample (asymptotic), normality test is done with Jarque-Bera test. The Jarque-Bera has a chi square value with two degrees of freedom. If the result of the Jarque-Bera test is greater than the value of chi square at $\alpha=5 \%$, then the null hypothesis is accepted, which means the data distribution is normal. If the result of the Jarque-Bera test is lesser than the value of chi square at $\alpha=$ 
$5 \%$, then the null hypothesis is rejected, which means the data distribution is not normal.

Multicollinearity test. According to Kuncoro (2005), multicollinearity test is the existence of a perfect (near perfect) linear relationship between some or all of the independent variables. Multicollinearity test aims to test whether the regression model finds a correlation between independent variables. The cutoff value used to indicate multicollinearity is a tolerance value $\leq 0.10$ or the same as the Variance Inflation Factor (VIF) value $\geq 10$.

Heteroscedasticity test aims to test whether in the regression model there is an inequality of residual variable from one observation to another. This test uses the White Test by looking at the Chi-square probability value. If the Chi-square probability value is greater than the significance level $\alpha=0.05$, there is no heteroscedasticity.

Autocorrelation test is useful for finding out whether there is a strong positive or negative relationship between the data of the variables in a linear regression model (Suliyanto, 2011). If a correlation takes place, then it is said that there is an autocorrelation problem. A good regression model is a regression that is free from autocorrelation.

\subsection{Operational definition of variables}

The dependent variable in this study is earnings management. Earnings management is defined as a manager's attempt to engineer financial statements within the limits permitted by accounting principles which aim to cause asymmetric information to the users of financial statements for the benefit of the managers (Meutia, 2004). In this study, earnings management is measured using discretionary accruals which refers to the modified Jones model (Dechow et al., 1995).

$$
\text { DACC }_{t}=\frac{\text { TACC }_{t}}{\text { ASSETS }_{t-1}}-\text { NDACC }
$$

The independent variables of this study are as follow.

The size of the Board of Directors. The composition of the board of directors must be compiled of such that it enables effective, precise, and fast decision-making and can act independently (National Committee on Governance Policy or Komite Nasional Kebijakan Governance, 2006). The size of the board of directors is obtained from the total number of directors in the board of commissioners of the sample company.

The proportion of independent commissioners is measured by the percentage of the number of independent commissioners divided by the overall members of the board of commissioner in the company. The measurement scale is the ratio.

$$
\mathrm{KI}=\frac{\text { The number of independent commissioners }}{\text { The overall members of the board of commissioners }} \times 100 \%
$$

The audit committee is a committee that is formed by the board of commissioners to carry out the duty of supervising the management of the company. Jakarta Stock Exchange circular No. SE- 008/BEJ/12-2001 dated December $7^{\text {th }}, 2001$ and guidelines for the formation of an audit committee based on BAPEPAM regarding the membership of the audit committee stated that the number of members of the audit committee is at least 3 (three) people, including the chairman of the audit committee. The variable of the number of audit committees in this study is measured using the number of audit committee members in the company. 
Company size can be measured using asset benchmarks. Because the company's total assets are large, thus it can be simplified by transforming it into natural logarithms (Ghozali and Chariri, 2007); hence, the size of the company can also be calculated by:

\section{Size $=$ Ln Total Assets}

Free cash flow. Ehrhardt and Brigham (2011:59) state that free cash flow means cash flow that is truly available to be paid to all investors after the company puts all of its investment in fixed assets, new products, and working capital that is required to maintain operations that are still running. According to Guinan (2010), the free cash flow can be formulated as follows:

Free cash flow $=$ Operating cash flow - Capital Expenditures

\section{RESULTS AND DISCUSSIONS}

\subsection{Results}

Table 1 shows that the UDD, KI, JKA and UP variables have mean values that are greater than the standard deviation values. This shows that the quality of the data of these variables is good because the mean values are greater than the standard deviation values, identifying that the standard errors of the variables are small. While the FCF and MNJ variables have mean values that are smaller than the standard deviation values, thus it can be identified that the standard errors of these variables are large.

Table 1. Descriptive Statistics

\begin{tabular}{lcccccc}
\hline & UDD & KI & JKA & UP & FCF & MNJ \\
\hline Mean & 5.644444 & 37.90516 & 2.866667 & 28.91256 & $1.25 \mathrm{E}+12$ & 0.708861 \\
Median & 5.000000 & 33.33333 & 3.000000 & 28.45302 & $2.67 \mathrm{E}+11$ & 0.571883 \\
Maximum & 9.000000 & 66.66667 & 4.000000 & 32.08466 & $8.80 \mathrm{E}+12$ & 10.29615 \\
Minimum & 2.000000 & 0.375000 & 0.000000 & 26.38956 & $-1.53 \mathrm{E}+12$ & -3.569569 \\
Std. Dev. & 2.079724 & 9.525741 & 0.814639 & 1.477245 & $2.07 \mathrm{E}+12$ & 1.751169 \\
Skewness & 0.467640 & -0.296980 & -2.814994 & 0.591245 & 1.950833 & 3.379941 \\
Kurtosis & 2.101286 & 8.519688 & 10.95431 & 2.246177 & 6.526729 & 21.81442 \\
Jarque-Bera & 3.154566 & 57.78701 & 178.0645 & 3.687246 & 51.86401 & 749.3973 \\
Probability & 0.206535 & 0.000000 & 0.000000 & 0.158243 & 0.000000 & 0.000000 \\
Sum & 254.0000 & 1705.732 & 129.0000 & 1301.065 & $5.64 \mathrm{E}+13$ & 31.89874 \\
Sum Sq. Dev. & 190.3111 & 3992.548 & 29.20000 & 96.01908 & $1.89 \mathrm{E}+26$ & 134.9301 \\
Observations & 45 & 45 & 45 & 45 & 45 & 45 \\
\hline
\end{tabular}

In order to perform multiple regression analysis, there are several models to choose from, which include the common effect model, the fixed effect model and the random effect model. Table 2 shows that the first stage that will be carried out is the Chow test where the probability value on the F-Test is 0.1524 , this value is greater than 0.05 , thus it can be concluded that the model follows the Common Effect Model (CEM).

Table 2. Chow test

\begin{tabular}{lccc}
\hline \multicolumn{1}{c}{ Effects Test } & Statistic & d.f. & Prob. \\
\hline Cross-section F & 1.603848 & $(9,35)$ & 0.1524 \\
Cross-section Chi-square & 17.265159 & 9 & 0.0447 \\
\hline
\end{tabular}

Table 3 shows that the second stage to be carried out is the Hausman test, Based on table 3, where the probability value at the Chi-Square value is 0.3331 , this value is greater than 0.05 , thus it can be concluded that based on the Hausman test, the model follows the Random Effect Model (REM). 
Table 3. Hausman test

\begin{tabular}{cccc}
\hline Test Summary & Chi-Sq. Statistic & Chi-Sq. d.f. & Prob. \\
\hline Cross-section random & 5.732911 & 5 & 0.3331 \\
\hline
\end{tabular}

Figure 1 shows the result of the normality test for the residual error in figure 1 where Jarque Bera value is 3.364519 with $\mathrm{p}$ value of 0,185953 which is $>0.05$, hence $\mathrm{H} 0$ is accepted, which means that the residual error of the model is normally distributed.

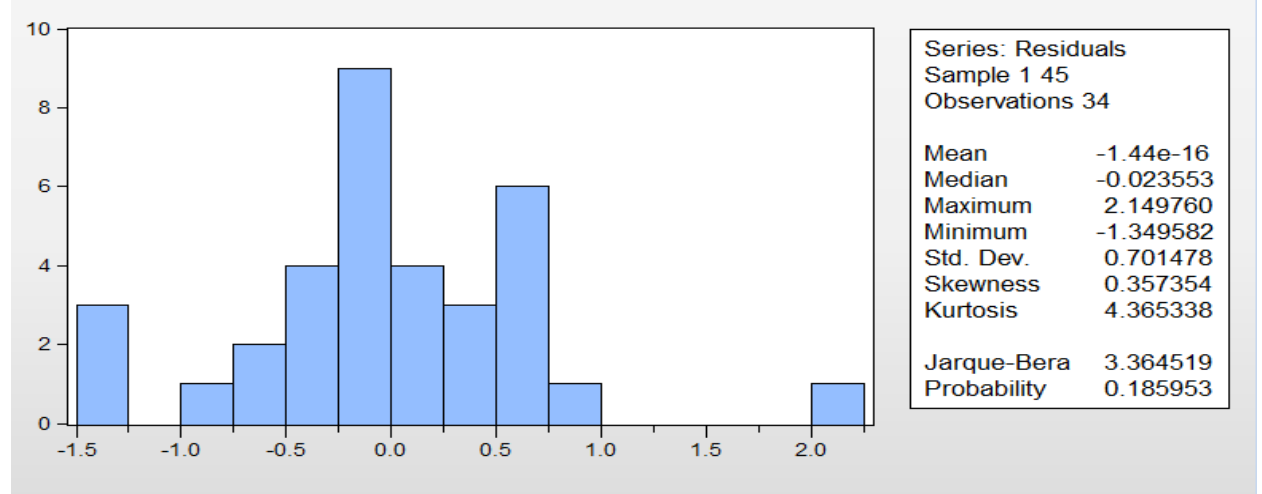

Figure 1. Normality test

Table 4 presents the results of the Variance Inflation Factors (VIF) values which shows that none of the independent variables have VIF value of greater than 10 . Thus, it can be concluded that there is no multicollinearity between the independent variables in this model.

Table 4. Multicollinearity test

\begin{tabular}{lccc}
\hline \multicolumn{1}{c}{ Variable } & Coefficient Variance & Uncentered VIF & Centered VIF \\
\hline C & 61.88151 & 1014.489 & NA \\
UDD & 0.031706 & 18.75884 & 2.198286 \\
PKI & 0.000857 & 21.42888 & 1.246287 \\
JKA & 0.119649 & 17.39218 & 1.272811 \\
UP & 0.084449 & 1160.279 & 2.954114 \\
FCF & $4.55 \mathrm{E}-26$ & 4.298123 & 3.128681 \\
\hline
\end{tabular}

Table 5 presents the result of heteroscedasticity test which shows that the p value by the Prob. value chi square on Obs * R-Squared is 0.3689 which is $>0.05$, hence $\mathrm{H} 0$ is accepted, which means that there is no heteroscedasticity.

Table 5. Heteroscedasticity test

\begin{tabular}{llll}
\hline F-statistic & 1.096692 & Prob. F (20,24) & 0.4104 \\
Obs*R-squared & 21.48793 & Prob. Chi-Square(20) & 0.3689 \\
Scaled explained SS & 124.1409 & Prob. Chi-Square(20) & 0.0000 \\
\hline
\end{tabular}

Table 6 shows that the value of Prob Chi Square has the p value on the Breusch-Godfrey Serial Correlation LM test, that is 0.9912, which is > 0.05, hence H0 is accepted, which means there is no autocorrelation problem.

Table 6. Autocorrelation test

\begin{tabular}{llll}
\hline F-statistic & 0.008828 & Prob. F (2,37) & 0.9912 \\
Obs*R-squared & 0.021463 & Prob. Chi-Square(2) & 0.9893 \\
\hline
\end{tabular}


Table 7 presents the results of multiple regression analysis where the probability value of the size of the board of directors (UDD) and the probability value of independent commissioners $(\mathrm{KI})>(0.05)$ which means that both of these variables have an effect on earnings management. On the contrary, the probability value of the number of audit committees (JKA), the probability value of company size (UP), and the probability value on free cash flow to earnings management $<(0.05)$, thus it is showing that these three variables have no effect on earnings management. The regression equation that resulted is as follows: $Y=-8.264250+0,359979 U D D+0,073766 K I-0,148988 J K A+0,169065 U P-2,44^{E}{ }_{-}{ }^{13} F C F$

\section{Table 7. Multiple regression}

\begin{tabular}{lcccc}
\hline \multicolumn{1}{c}{ Variable } & Coefficient & Std. Error & t-Statistic & Prob. \\
\hline C & -8.264250 & 7.240038 & -1.141465 & 0.2599 \\
UDD & 0.359979 & 0.159241 & 2.260589 & 0.0288 \\
KI & 0.073766 & 0.026691 & 2.763738 & 0.0083 \\
JKA & -0.148988 & 0.319333 & -0.466559 & 0.6431 \\
UP & 0.169065 & 0.268737 & 0.629108 & 0.5325 \\
FCF & $-2.44 E-13$ & $1.73 E-13$ & -1.406422 & 0.1666 \\
R $^{2}$ & 0.229447 & & & \\
\hline
\end{tabular}

Table 8 presents the results of the correlation analysis which shows that all independent variables are correlated with the dependent variable. This means that the independent variables have a relationship with the dependent variable.

Table 8. Correlation test

\begin{tabular}{lcrrrc}
\hline & UDD & \multicolumn{1}{c}{ KI } & JKA & UP & FCF \\
\hline UDD & 1.000000 & -0.259638 & 0.320161 & 0.621454 & 0.644834 \\
PKI & -0.259638 & 1.000000 & -0.317781 & 0.018436 & 0.034503 \\
JKA & 0.320161 & -0.317781 & 1.000000 & 0.248165 & 0.100023 \\
UP & 0.621454 & 0.018436 & 0.248165 & 1.000000 & 0.784755 \\
FCF & 0.644834 & 0.034503 & 0.100023 & 0.784755 & 1.000000 \\
\hline
\end{tabular}

\subsection{Discussions}

The Size of the Board of Directors and Earnings Management. Based on the results of the analysis, the size of the board of directors partially affects earnings management. This suggests that the large number of the board of directors can ensure the effectiveness of management in carrying out its functions and can suppress the practice of earnings management. This result is not in line with Oktaviani (2016) who finds that the size of the board of directors had no effect on earnings management, hence the size of the board of directors was not able to guarantee the effectiveness in carrying out the monitoring function towards the performance of the management.

The proportion of Independent Commissioners and earnings management. Based on the results of the analysis, the proportion of independent commissioners partially affects earnings management. The result of this study is in line with Nabila and Daljono (2013) who find that the proportion of independent commissioners had a significant effect on earnings management because the independent party had no ties or interests to the management, so that it was free from the pressure and managerial intervention. The more the number of independent commissioners are, the better the quality of the supervision will be, along with the many demands from independent parties who want transparency. On the contrary, the result of this study is not in line with Marpaung and Latrini (2014) who find that the objective 
of presenting an independent commissioner is to balance the decision making of the board of commissioners.

The number of Audit Committees and earnings management. Based on the results of the analysis, the number of audit committees partially has no effect on earnings management. This study is in line with Oktaviani (2016) who find that the audit committee had no effect on earnings management practices because the number of audit committees is only meant as a formality to comply with government regulations.

The company size on earnings management. Based on the results of the analysis, the company size variable partially has no effect on earnings management. This study is in line with Gunawan et al. (2015) who find that the size of the company had no significant effect on earnings management. Thus, it shows that the size of the company does not necessarily reduce the possibility of earnings management formation.

Free cash flow and earnings management. Based on the results of the analysis, the free cash flow variable partially has no effect on earnings management. This study is not in line with Agustia (2013), and Kodriyah and Fitri (2017) who find that free cash flow had a significant effect on earnings management.

\section{CONCLUSION}

\subsection{Conclusion}

Based on the analysis result and discussion that has been carried out, from the results of the test in this study it can be concluded that the size of the board of directors and the proportion of independent commissioners has an effect on earnings management, while the number of audit committees, company size and free cash flow have no effect on earnings management. The results of this study imply that from the point of view of agency theory, the higher the practice of earnings management, the more likely it is to increase the control of management from shareholders representatives as a form of good governance.

\subsection{Suggestion}

Based on the conclusions, the next study need to increase the number of samples to be wider and more varied. Aside from that, the next study should add other variables that have not been examined yet by the author, as well as using different models in discretionary accrual calculations in order to be able to see earnings management from a different point of view. Furthermore, open entities need to pay attention to other factors that can minimize earnings management, from the point of view of the implementation of good corporate governance, company size and free cash.

\section{REFERENCES}

Agus, S. (2010). Manajemen keuangan teori dan aplikasi, Edisi Keempat. Yogyakarta: BPFE.

Agustia, D. (2013). Pengaruh faktor good corporate governance, free cash flow, dan leverage terhadap manajemen laba. Jurnal Akuntansi dan Keuangan, 15(1), 27-42. https://doi.org/10.9744/jak.15.1.27-42

Dechow, P. M., Sloan, R. G., \& Sweeney, A. P. (1995). Detecting earnings management. The Accounting Review, 70(2), 193-225. https://www.jstor.org/stable/248303

Ehrhardt, M. C., \& Brigham, E. F. (2011). Financial management: Theory and practice, $13^{\text {th }}$ Edition. United States: South-Western Cengage Learning.

FCGI. (2002). Corporate governance: Tata kelola perusahaan, Edisi Ketiga. Jakarta.

Ghozali, I., \& Chariri, A. (2007). Teori akuntansi. Semarang: Badan Penerbit Universitas Diponegoro. 
Ghozali, I., \& Ratmono, D. (2013). Analisis multivariat dan ekonometrika, teori, konsep, dan aplikasi dengan eviews 8. Semarang: Badan Penerbit Universitas Diponegoro.

Gregory, H. J. (2000). International comparison of corporate governance guidelines and codes of best practice: Investor viewpoints. https://ecgi.global/download/file/fid/9175

Guinan, J. (2010). Investopedia: Cara mudah memahami istilah investasi. Jakarta: PT Mizan Publika.

Gunawan, I. K., Darmawan, N. A. S., \& Purnamawati, I. G. A. (2015). Pengaruh ukuran perusahaan, profitabilitas, dan leverage terhadap manajemen laba pada perusahaan manufaktur yang terdaftar di Bursa Efek Indonesia (BEI). JIMAT (Jurnal Ilmiah $\begin{array}{lll}\text { Mahasiswa Akuntansi } & \text { Undiksha, 3(1). }\end{array}$ https://ejournal.undiksha.ac.id/index.php/S1ak/article/view/5272

Handayani, R. S., \& Rachadi, A. D. (2009). Pengaruh ukuran perusahaan terhadap manajemen laba. Jurnal Bisnis dan Akuntansi, 11(1), 33-56, https://www.neliti.com/publications/321544/pengaruh-ukuran-perusahaan-terhadapmanajemen-laba

Handoko, J. (2014). Pengaruh struktur modal dan mekanisme corporate governance terhadap agency cost perusahaan LQ45 di BEI Tahun 2013. http://repository.wima.ac.id/994/

Jensen, M. C., \& Meckling, W. H. (1976). Theory of the firm: Managerial behavior, agency costs and ownership structure. Journal Of Financial Economics, 3(4), 305-360. http://doi.org/10.1016/0304-405X(76)90026-X

Juwika, F. A., \& Hani, S. (2015). Mekanisme good corporate governance terhadap manajemen laba pada perusahaan manufaktur yang terdaftar di Bursa Efek Indonesia. Jurnal Akuntansi dan Bisnis, 1(1), 35-48. http://ojs.uma.ac.id/index.php/jurnalakundanbisnis/article/view/96

BAPEPAM, LK. (2012). Pembentukan dan pedoman pelaksanaan kerja komite audit. https://www.ojk.go.id/Files/regulasi/pasar-modal/bapepam-pm/emiten-pp/peraturanlain/6.IX.I.5.pdf

Kodriyah, K., \& Fitri, A. (2017). Pengaruh free cash flow dan leverage terhadap manajemen laba pada perusahaan manufaktur di BEI. JAK (Jurnal Akuntansi): Kajian Ilmiah Akuntansi, 4(1). https://doi.org/10.30656/jak.v4i1.218

Komite Nasional Kebijakan Governance, K. (2006). Pedoman umum good corporate governance Indonesia. https://ecgi.global/sites/default/files/codes/documents/indonesia_cg_2006_id.pdf

Kuncoro, M. (2005). Metode kuantitatif. Yogyakarta: Unit penerbit dan percetakan AMP YKPN.

Mahiswari, R., \& Nugroho, P. I. (2014). Pengaruh mekanisme corporate governance, ukuran perusahaan dan leverage terhadap manajemen laba dan kinerja Keuangan. Jurnal Ekonomi dan Bisnis, 17(1), 1-20. https://doi.org/10.24914/jeb.v17i1.237

Marpaung, C. O., \& Latrini, N. M. Y. (2014). Pengaruh dewan komisaris independen, komite audit, kualitas audit dan kepemilikan manajerial pada perataan laba. E-Jurnal Akuntansi Universitas Udayana, 7(2014), 279-289. https://ojs.unud.ac.id/index.php/Akuntansi/article/view/8832

Medyawati, H., \& Dayanti, A. S. (2017). Pengaruh ukuran perusahaan terhadap manajemen laba: Analisis data panel. Jurnal Ilmiah Ekonomi Bisnis, 21(3). https://ejournal.gunadarma.ac.id/index.php/ekbis/article/view/1513

Meutia, I. (2004). Pengaruh independensi auditor terhadap manajemen laba untuk KAP big 5 dan non big 5. The Indonesian Journal of Accounting Research, 7(3). https://ijariaikapd.or.id/index.php/ijar/article/view/125

Mutmainnah, N., \& Wardhani, R. (2013). Analisis dampak kualitas komite audit terhadap kualitas laporan keuangan perusahaan dengan kualitas audit sebagai variabel 
moderasi. Jurnal Akuntansi dan Keuangan Indonesia, 10(2), 147-170. http://jaki.ui.ac.id/index.php/home/article/view/191

Nabila, A., \& Daljono, D. (2013). Pengaruh proporsi dewan komisaris independen, komite audit, dan reputasi auditor terhadap manajemen laba. Diponegoro Journal of Accounting,

99-108. https://ejournal3.undip.ac.id/index.php/accounting/article/view/2286

Nasution, M., \& Setiawan, D. (2007). Pengaruh corporate governance terhadap manajemen laba di industri perbankan Indonesia. Simposium Nasional Akuntansi X, 1(1), 1-26. http://pdeb.fe.ui.ac.id/?p=7124

Oktaviani, H. D. (2016). Pengaruh ukuran dewan direksi, proporsi dewan, komisaris independen, dan ukuran komite audit terhadap praktik manajemen laba pada perusahaan farmasi yang terdaftar di BEI Tahun 2009-2014. Jurnal Akuntansi UNESA, 4(2), 1,24. https://jurnalmahasiswa.unesa.ac.id/index.php/jurnalakuntansi/article/view/14728

Pradipta, A. (2011). Analisis pengaruh dari mekanisme corporate governance terhadap manajemen laba. Jurnal Bisnis dan Akuntansi, 13(2), 93 -106. https://jurnaltsm.id/index.php/JBA/article/view/110

Putra, R. N. A. (2019). Good corpotare governance dan manajemen laba di Perbankan Syariah. Journal of Islamic Finance and Accounting, 2(2), 19-38. http://doi.org/10.22515/jifa.v2i2.1925

Sochib, S. (2015). Pengaruh penerapan good corporate governance terhadap manajemen laba serta kinerja keuangan. Wiga: Jurnal Penelitian Ilmu Ekonomi, 5(1), 34-45. https://www.neliti.com/publications/36680/pengaruh-penerapan-good-corporategovernance-terhadap-manajemen-laba-serta-kiner

Subramanyam, K. R., \& John, J. W. (2010). Analisis laporan keuangan (Financial Statement Analysis), Edisi Kesepuluh, Terjemahan Dewi Yanti, Jilid 2. Jakarta: Salemba Empat.

Sukandar, P. P., \& Rahardja, R. (2014). Pengaruh ukuran dewan direksi dan dewan komisaris serta ukuran perusahaan terhadap kinerja keuangan perusahaan (studi empiris pada perusahaan manufaktur sektor consumer good yang terdaftar di BEI tahun 20102012). Diponegoro Journal of Accounting, 689-695. http://ejournals1.undip.ac.id/index.php/accounting

Suliyanto, D. (2011). Ekonometrika terapan: teori dan aplikasi dengan SPSS. Yogyakarta: Penerbit Andi

Yasmeen, D., \& Hermawati, S. (2015). Pengaruh good corporate governance terhadap kualitas pelaporan keuangan pada perusahaan manufaktur. Jurnal Ilmiah Ekonomi Bisnis, 20(1). https://ejournal.gunadarma.ac.id/index.php/ekbis/article/view/1152 